\title{
Fomitopsis officinalis (Polyporales): are there any records of the fungus known from Ukraine?
}

\author{
Vera P. HAYOVA, Vasyl P. HELUTA, Mariya V. SHEVCHENKO \\ M.G. Kholodny Institute of Botany, National Academy of Sciences of Ukraine \\ 2 Tereshchenkivska Str., Kyiv 01004, Ukraine \\ v.hayova@gmail.com
}

\begin{abstract}
Hayova V.P., Heluta V.P., Shevchenko M.V. 2019. Fomitopsis officinalis (Polyporales): are there any records of the fungus known from Ukraine? Ukrainian Botanical Journal, 77(1): 40-43.

Abstract. Fomitopsis officinalis is listed in the Red Data Book of Ukraine as an extinct species. According to the data published therein on its former distribution in Ukraine, the species was reported in Ivano-Frankivsk and Lviv regions in the first half of the $20^{\text {th }}$ century. However, our analysis of the bibliographic references listed for this species has revealed no records of the fungus in the country. The article provides a brief overview of the published literature sources used as a basis for its red-listing on the national level. Most probably the information on the occurrence of F. officinalis in Ukraine derived from other countries where the fungus, particularly in the past, was most common and its fruit bodies were extensively collected. Since historical data on the occurrence of F. officinalis in Ukraine are highly doubtful, the species should be excluded from the Red Data Book of Ukraine.
\end{abstract}

Keywords: fungal conservation, larch fungus, Laricifomes officinalis, Red Data Book of Ukraine

Submitted 20 January 2020. Published 28 February 2020

Гайова В.П., Гелюта В.П., Шевченко М.В. 2019. Fomitopsis officinalis (Polyporales): чи відомі знахідки цього гриба в Україні? Украӥнський ботанічний журнал, 77(1): 40-43.

Інститут ботаніки ім. М.Г. Холодного НАН України

вул. Терещенківська 2, Київ 01004, Україна

Реферат. Fomitopsis officinalis включений до Червоної книги України як зниклий вид. Згідно 3 опублікованими в цій книзі даними про його колишнє поширення в Україні, гриб був відомий в Івано-Франківській та Львівській областях у першій половині XX століття. Проте у бібліографічних джерелах, поданих до нарису про цей вид, інформація про знахідки F. officinalis у нашій країні не наводиться. У статті представлено короткий огляд публікацій, на підставі яких вид було включено до Червоної книги України. Робиться висновок про те, що вказівка щодо трапляння F. officinalis в Україні є помилковою унаслідок некоректної екстраполяції на ії територію загальних даних про поширення виду в інших країнах Європи. Тому цей вид слід виключити з Червоної книги України.

Ключові слова: Laricifomes officinalis, губка модринова, охорона грибів, Червона книга України

(C) 2020 V.P. Hayova, V.P. Heluta, M.V. Shevchenko. Published by the M.G. Kholodny Institute of Botany, NAS of Ukraine. This is an open access article under the terms of the Creative Commons Attribution License (http://creativecommons.org/licenses/by/4.0/), which permits use, distribution, and reproduction in any medium, provided the original work is properly cited 
Fomitopsis officinalis (Batsch) Bondartsev \& Singer is a polyporoid fungus that forms large perennial fruit bodies on old standing trees, rarely on fallen logs or stumps. It is a slow-growing weak parasite causing cubic brown rot of heartwood of living trees. Although $F$. officinalis attacks living tissues, it may colonize tree trunks over decades and continues to decompose wood of the dead hosts as a saprotroph. The fungus produces easily recognizable fruit bodies, at first ungulate, later columnar to cylindrical, often reaching a considerable size. Apart from distinctive external morphological characters, its fruit bodies differ from those of other species by chalky white consistency, crumbly texture, bitter taste and special flavor (Bernicchia, 2005; Ryvarden, Melo, 2014).

The fungus is also known under the name Laricifomes officinalis (Batsch) Kotl. \& Pouzar. Based on several distinctive macromorphological characters, Kotlaba \& Pouzar (1957) transferred the species to the monotypic genus Laricifomes Kotl. \& Pouzar. Subsequently, several molecular phylogenetic studies demonstrated that $L$. officinalis forms a separate lineage and thus represents a separate monophyletic genus distant from Fomitopsis s.s. (Kim et al., 2005; Han et al., 2016). However, F. officinalis still remains a currently widely accepted name of the fungus, while $L$. officinalis is listed as one of the synonyms (http://www.speciesfungorum. org, http://www.mycobank.org).

Fomitopsis officinalis has a Holarctic distribution; the fungus occurs predominantly in subalpine, montane and boreal forests of the Northern hemisphere and is very rare almost everywhere throughout its range. The species was reported from Europe (Austria, Belgium, France, Germany, Italy, Lithuania, Netherlands, Poland, Romania, Russian Federation, Slovakia, Slovenia, Spain, Switzerland), Asia (China, India, Japan, Korea, Mongolia, Russian Federation, Turkey), North Africa (Morocco), and North America (Canada, USA) (Distribution..., 2015). Three major distribution areas of the species are as follows: Western Europe (the Alps), North Asia (Siberia from the Ural Mountains to the Russian Far East), and North America. Other reported localities from Asia and North Africa represent small and geographically very restricted populations of the fungus.

The host plants of $F$. officinalis differ across its general distribution range. In North America, the fungus has been reported on several hosts of Pinaceae (Abies Mill., Larix Mill., Picea A.Dietr., Pinus L., Pseudotsuga Carrière, and Tsuga Carrière) (Gilbertson, Ryvarden, 1986), while in Eurasia it occurs mostly on Larix spp. and only occasionally on Pinus spp. In Europe, F. officinalis has been recorded almost exclusively on Larix decidua Mill., with a few exceptions. In the European part of Russia (the Urals and adjacent areas), the fungus occurs on Larix sibirica Ledeb. and Pinus sibirica Du Tour (Chlebicki et al., 2003; Shiryaev et al., 2010). In Spain, a collection from $P$. nigra subsp. salzmannii (Dunal) Franco (syn. P. clusiana Clemente) has been reported (Telleria, 1980).

Distribution of $F$. officinalis in Europe largely coincides with the native range of $L$. decidua, the main host of the species within the continent. Larix decidua is discontinuously distributed in the mountain regions of Southern, Central and Eastern Europe. The species has a broad vertical range, forming forests at various altitudes, between $2500 \mathrm{~m}$ in the central Alps and $180 \mathrm{~m}$ in Poland (Da Ronch et al., 2016). Two subspecies are currently accepted: L. decidua subsp. decidua and L. decidua subsp. polonica (Wóycicki) Domin (syn. Larix polonica Wóycicki) (Raab-Straube, 2014) that show different distribution patterns. The former subspecies covers a compact area in the highest European mountain range, in the Alps, from south-eastern France to northern Slovenia, while the latter one is represented by patchy populations at lower altitudes, in the Sudetes mountains, the Eastern Carpathians, as well as upland and lowland areas in Poland.

In Ukraine, L. decidua subsp. polonica is listed in the Red Data Book of Ukraine (2009) (as L. polonica). This species (or subspecies) occurs naturally only in two small separate localities in the Gorgany and Chornohora mountain ranges which are included, respectively, in two botanical reserves, the Manyava Skyt forest parcel (Ivano-Frankivsk Region) and Kedryn forest parcel (Transcarpathian Region). In both reserves, it forms mixed stands with Pinus cembra L. and Picea abies (L.) H.Karst.

Consequently, in Europe $F$. officinalis has been reported mostly from high mountains and subalpine regions, occasionally from uplands and lowlands (Piętka, Szczepkowski, 2004; Wojewoda, 2010; Dakskobler et al., 2011). It occurs almost exclusively in natural forests and is very uncommon in artificial plantations. Moreover, the fungus is largely associated with virgin subalpine larch forests; it is therefore regarded as an important indicator of old-growth undisturbed forests of L. decidua (Distribution..., 2015).

Fomitopsis officinalis is currently known as one of the species threatened with extinction, both in Europe and globally (http://iucn.ekoo.se/iucn/species view/297501/). The species is red-listed and/or protected by law in at least ten European countries. Its populations 
have dramatically declined in all European countries over the last centuries due to human activities. For example, in Poland F. officinalis was rather common until the $19^{\text {th }}$ century, while currently only six localities of the fungus remain, mostly in the Świętokrzyskie Mountains (Piętka, Szczepkowski, 2004; Łuszczyńska, Łuszczyński, 2009).

The primary threats to this species are largely the same as those to other rare wood-inhabiting fungi, i.e. habitat destruction, overlogging of montane forests, cutting of individual old trees for timber, unsustainable forest management etc. Apart from habitat degradation and loss, another major threat is over-harvesting of fruit bodies for commercial trade. Since ancient times, F. officinalis commonly known as Agarick has been used for medicinal purposes. Due to their antimicrobial and antiviral activities, the fungal extracts have been continuously used by pharmacists in Europe over centuries. In the late $19^{\text {th }}$ and early $20^{\text {th }}$ centuries, its fruit bodies were extensively collected in large amounts for production of various natural medicines and for trade, primarily from Siberia (the Ural Mountains) and the Alps where the species was most common (Chlebicki et al., 2003; Piętka, Szczepkowski, 2004; Girometta, 2018).

In Ukraine, F. officinalis is listed in the third edition of the Red Data Book of Ukraine (2009) under its synonymic name, Laricifomes officinalis. The conservation status of the fungus at the national level was determined as an extinct species. According to its former distribution data, the fungus used to be known in the first half of the $20^{\text {th }}$ century in the Carpathians and western Ukrainian forests (Ivano-Frankivsk and Lviv regions). This conclusion was made following several bibliographic references, viz. a monograph by Bondartsev (1953) and two earlier manuals on medicinal plants, by Rytov (1918) and Panych (1924). However, none of these publications provides any specific data on the occurrence of $F$. officinalis in Ukraine.

In the monograph Polyporaceous fungi of the European part of the USSR and the Caucasus, Bondartsev (1953, p. 308) claimed that $F$. officinalis "occurs everywhere where larch and cedar (Rus.: кедр, i.e. Pinus sibirica, often erroneously referred to as Siberian cedar - VH) grow in large numbers"; however, he specified only three such areas, namely Perm, Kirov and Sverdlovsk oblasts (Russia). Apart from those areas, Bondartsev did not mention any other possible localities for $F$. officinalis, although distribution data in Ukraine for many species was provided, including personal collections of the author. This also applies to the other two cited above publications of the early $20^{\text {th }}$ century. Rytov (1918) presented information on enormous collections of the fruit bodies of larch fungus in Arkhangelsk Oblast (Russia) regularly exported to Hamburg (Germany) for trade purposes. Panych (1924, pp. 38-39) in his manual for local collectors of medicinal plants published in Lviv provided a brief description of Polyporus officinalis Fr., emphasized medical and commercial importance of the fungus but gave no evidence of its occurrence in the country. The statement that "fruit bodies can be collected all year round in unlimited amounts" is particularly doubtful due to very restricted areas of larch forests in the country. Most probably, this manual, like other similar editions of the first decades of the $20^{\text {th }}$ century, includes not only medicinal plants of local origin used in the pharmaceutical practice of western Ukraine (in Halychyna, or Galicia), but also those adopted from the pharmacopoeia lists published earlier in the AustroHungarian Empire and the Russian Empire (Makukh et al., 2013).

Similarly, F. officinalis is vaguely mentioned in the Handbook on Fungi of Ukraine (Zerova et al., 1972), with questionable distribution data. No records of the fungus have been reported in any published lists of mycological surveys ever conducted in the Ukrainian Carpathians or in the country as a whole. The species was neither registered in any historical mycological catalogues nor listed in the appropriate indices, for example, in the handbook on forest plant pathology published in Lviv (Shevchenko, 1968). Accordingly, no records for Ukraine are indicated on the distribution map of $F$. officinalis in Europe (Distribution..., 2015). Incidentally, there are three strains of $F$. officinalis in the IBK Mushroom Culture Collection of the M.G. Kholodny Institute of Botany, NAS of Ukraine; however, they are of various geographical origin outside Ukraine (Mykchaylova et al., 2017; Bisko et al., 2018).

Thus, information on the occurrence of $F$. officinalis in Ukraine appears at least highly doubtful. It should be also emphasized that this fungus, which is strictly associated with old trees of Larix, usually occurs in old-growth larch forests that are exceptionally rare in our country. If its occurrence cannot be proven with certainty, the species is to be excluded from the Red Data Book of Ukraine. 


\section{References}

Bernicchia A. 2005. Polyporaceae s. 1. In: Fungi Europaei, vol. 10. Alassio: Edizioni Candusso, 808 pp.

Bisko N.A., Sukhomlyn M.M., Mykchaylova O.B., Lomberg M.L., Tsvyd N.V., Petrichuk Yu.V., Al-Maali G.A., Mytropolska N.Yu. 2018. Ex situ conservation of rare and endangered species in mushroom culture collections of Ukraine. Ukrainian Botanical Journal, 75(4): 338-347. https://doi.org/10.15407/ukrbotj75.04.338

Bondartsev A.S. 1953. Polyporaceous fungi of the European part of the USSR and the Caucasus. Moskow; Leningrad: Acad. Sci. USSR, 1106 р. [Бондарцев А.C. 1953. Трутовые грибы Европейской части СССР и Кавказа. Москва; Ленинград: Изд-во АН СССР, 1106 с.].

Chlebicki A., Mukhin V., Ushakova N. 2003. Fomitopsis officinalis on Siberian larch in the Urals. Mycologist, 17(3): 1-6. https://doi.org/10.1017/ S0269-915X(03)00305-7

Dakskobler I., Seliškar A., Podgornik G. 2011. Razširjenost in ekologija vrste Laricifomes officinalis (Vill.) Kotl. \& Pouzar v Julijskih Alpah (Slovenija). Gozdarski Vestnik, 69, 3. Available at: https:/www.dlib.si/details/ URN:NBN:SI:DOC-5ITWR4MN/? (Accessed 16 January 2019).

Distribution, ecology and status of 51 macromycetes in Europe. Results of the ECCF Mapping Programme. 2015. A. Fraiture, P. Otto (Eds.). Scripta Botanica Belgica, vol. 53, 247 pp.

Gilbertson R.L., Ryvarden L. 1986. North American Polypores, vol. I. Oslo: Fungiflora, 443 pp.

Girometta C. 2018. Antimicrobial properties of Fomitopsis officinalis in the light of its bioactive metabolites: a review. Mycology, 10: 1-8. https://doi.org/10.1080/21501203.201 8.1536680

Han M.-L., Chen Y.-Y., Shen L.-L., Song J., Vlasák J., Dai Y.-C., Cui B.-K. 2016. Taxonomy and phylogeny of the brown-rot fungi: Fomitopsis and its related genera. Fungal Diversity, 80(1): 343-373. https://doi.org/10.1007/ s13225-016-0364-y

Kim K.M., Yoon Y.-G., Jung H.S. 2005. Evaluation of the monophyly of Fomitopsis using parsimony and MCMC methods. Mycologia, 97(4): 812-822. https://doi.org/10.1 080/15572536.2006.11832773

Kotlaba F., Pouzar Z. 1957. Notes on classification of European pore fungi. Česká Mykologie, 11(3): 152-170.

Da Ronch F., Caudullo G., Tinner W., de Rigo D. 2016. Larix decidua and other larches in Europe: Distribution, habitat, usage and threats. In European Atlas of Forest Tree Species. Eds. San-Miguel-Ayanz J., de Rigo D., Caudullo G., Houston Durrant T., Mauri A. Publication Office of the European Union: Luxembourg, pp. 108-110.

Łuszczyńska B., Łuszczyński J. 2009. Fomitopsis officinalis (Basidiomycota) population in the Góry Swiętokrzyskie Mountains. In: Mirek Z., Nikiel A. (Eds). Rare, relict and endangered plants and fungi in Poland. Kraków: W. Szafer Institute of Botany, Polish Academy of Sciences, $573 \mathrm{pp}$.

Makukh K.I., Fedushchak A.L., Melnyk Ya.R., Leskova A.V. 2013. Historical aspects of phytopharmacy in Galicia in the first half of the XX century. Clinical Pharmacy, Pharmacotherapy and Medical Standardization, 3-4: 2429. [Макух X.I., Федущак А.Л., Мельник Я.Р., Лескова А.В. 2013. Історичні аспекти фітофармації Галичини першої половини XX століття. Клінічна фармація, фармакотерапія та медична стандартизачія, 3-4: 24-29].

Mykchaylova O.B., Bisko N.A., Sukhomlyn M.M., Lomberg M.L., Pasaylyuk M.V., Petrichuk Y.V., Gryganskyi A.P. 2017. Biological peculiarities of a rare medicinal mushroom Fomitopsis officinalis (Fomitopsidaceae, Polyporales) on agar media and plant substrates. Regulatory Mechanisms in Biosystems, 8(4): 469-475. https://doi.org/10.15421/021772

Panych T. 1924. Lichnychi rostyny. Pidruchnyk dlya zbyrachiv, $z$ vidbytkamy $i$ narodnymy nazvamy rostyn. Lviv: Spilka ukrainskykh kooperatyv Halychyny, 153 s. [Панич T. 1924. Лічничі ростини. Підручник для збирачів, з відбитками і народними назвами ростин. Львів: Спілка українських кооператив Галичини, 153 с.].

Piętka J., Szczepkowski A. 2004. Localities of Fomitopsis officinalis in Poland. Acta Mycologica, 39(1): 33-45.

Raab-Straube E. von. 2014. Gymnospermae. In: Euro+Med Plantbase - the information resource for Euro-Mediterranean plant diversity. Available at: http:/ww2.bgbm.org/ europlusmed/PTaxonDetail.asp?NameId=106452\&PTRef $\mathrm{Fk}=7500000$ (Accessed 16 January 2019).

Red Data Book of Ukraine. Plant kingdom. 2009. Ed. Ya.P. Didukh. Kyiv: Globalconsulting, 912 pp. [Червона книга Украӥни. Рослинний світ. 2009. Ред. Я.П. Дідух. Київ: Глобалконсалтинг, 912 с.].

Rytov M.V. 1918. Russkiya lekarstvennyia rasteniya. T. I. Dikorastushchiya $i$ vozdelyvaemyia lekarstvennyia rasteniya. Petrograd: Izd-vo P.P. Soykina, 256 s. [Рытов М.В. 1918. Русские лекарственные растения. T. I. Дикорастущие и воздельваемые лекарственные растения. Петроград: Изд-во П.П. Сойкина, 256 с.].

Ryvarden L., Melo I. 2014. Poroid fungi of Europe. Oslo: Fungiflora, $455 \mathrm{p}$.

Shevchenko S.V. 1968. Lisova fitopatolohiya. Lviv: Vyd-vo Lvivskoho un-tu. 343 pp. [Шевченко С.В. 1968. Лісова фітопатологія. Львів: Вид-во Львівського ун-ту. 343 c.].

Shiryaev A., Kotiranta H., Mukhin V.A., Stavishenko I.V., Ushakova N.V. 2010. Aphyllophoroid fungi of Sverdlovsk region, Russia: biodiversity, distribution, ecology and the IUCN threat categories. Ekaterinburg: Goshchitskiy Publisher, $304 \mathrm{pp}$.

Tellería M.T. 1980. Contribución al estudio de los Aphyllophorales españoles. Bibliotheca Mycologica, 74: $1-464$.

Wojewoda W. 2010. Laricifomes officinalis in the Gorce Mountains (S Poland). Acta Mycologica, 45(2): 129-131.

Zerova M.Ya., Radzievskyi G.G., Shevchenko S.V. 1972. Vyznachnyk hrybiv Ukrainy. Kyiv: Naukova Dumka, vol. 5, 240 pp. [Зерова М.Я., Радзієвський Г.Г., Шевченко С.В. 1972. Визначник грибів України, т. 5. Київ: Наук. думка, 240 с.].

Recommended for publication by M.M. Sukhomlyn 